\title{
DEVELOPMENT OF A DISSOLUTION TEST FOR MELATONIN SUBLINGUAL TABLETS USING A FACTORIAL EXPERIMENTAL DESIGN
}

\author{
LOURDES MAYET-CRUZ, JUAN MANUEL RODRÍGUEZ, HELGI JUNG-COOK * \\ Departamento de Farmacia, Facultad de Química, Universidad Nacional Autónoma de México. C.P., 04510, Ciudad de \\ México, México
}

*corresponding author: helgi@unam.mx

Manuscript received: August 2020

\begin{abstract}
The main objective of the present study was to develop a dissolution method for melatonin sublingual tablets. A factorial design type 2 was performed using agitation rate, dissolution media and sampling times as critical test parameters. For the experimental design, one commercial batch of the Mexican reference sublingual tablet product (5 mg) was used. The quantification of the drug released was performed using an UV assay at $220 \mathrm{~nm}$. The best results were obtained using USP Apparatus 2 (paddles) at $50 \mathrm{rpm}$ and $500 \mathrm{~mL}$ of water as dissolution medium. For the method evaluation, the dissolution profiles of two batches of a reference product and two batches of two commercially available melatonin generic products (5 $\mathrm{mg})$ were evaluated and compared using a model-independent analysis. Results showed the capacity of the method to discern between different products of melatonin sublingual tablets.
\end{abstract}

\section{Rezumat}

Obiectivul principal al prezentului studiu a fost dezvoltarea unei metode de dizolvare pentru comprimatele sublinguale cu melatonină. A fost realizat un design factorial de tip 2 folosind viteza de agitare, mediul de dizolvare şi timpii de reumplere ca parametri critici de testare. Pentru studiul experimental, a fost utilizat un lot comercial al produsului de referință din Mexic $(5 \mathrm{mg})$. Cuantificarea substanței eliberate a fost efectuată utilizând o metodă UV la $220 \mathrm{~nm}$. Cele mai bune rezultate s-au obținut folosind aparatul cu palete la $50 \mathrm{rpm}$ și $500 \mathrm{~mL}$ apă ca mediu de dizolvare. Pentru evaluarea metodei, profilurile de dizolvare a două loturi de produs de referință și două loturi de două produse generice cu melatonină disponibile comercial $(5 \mathrm{mg})$ au fost evaluate şi comparate, utilizând o analiză independentă de model. Rezultatele au arătat capacitatea metodei de a discerne între diferite produsele ce conțin comprimate sublinguale cu melatonină.

Keywords: melatonin, sublingual tablets, dissolution profiles, experimental design

\section{Introduction}

Melatonin (N-acetyl-5-methoxytryptamine) is a neurohormone derived from serotonin and produced by the pineal gland, the intestine and within mitochondria $[1,2]$. Melatonin is secreted in a circadian rhythmic manner with prominent nocturnal maximum function and is involved in the regulation of the sleep-wake cycle [3]. Additionally, it shows antioxidant properties and is related as a regulator of redox-relevant enzymes, thermoregulation, hormonal secretion and other physiologic events therefore it is also called al pleiotropic hormone [4]. Melatonin, a neutral molecule is a white-cream to yellowish crystalline powder, soluble in aqueous media. Recently it has been documented that the molecule has lipidic properties, and also crosses the blood-brain barrier [5, 6].

There is a wide variability in the regulatory status of melatonin. In the United States and in Canada it is available as a dietary supplement. Tablets, capsules and gummies are available and are widely used, usually on a daily basis, as a sleep aid, in doses of 0.3 to $5 \mathrm{mg}$.
In Europe, presently, there are two prolonged-release dosage forms approved as medicinal products while others are available as dietary supplements. In Mexico, melatonin is categorized as a medicinal product, approved for the short-term treatment of primary insomnia and used orally in immediate and modified release formulations, prior to sleep time in order to facilitate sleep onset [7]. The immediate release formulations are tablets in doses of $0.3,1,3$ and $5 \mathrm{mg}$, while the doses in sublingual tablets are 2.5 and $5 \mathrm{mg}$. Sustained release dosage forms are also available at doses of 2, 3 and $5 \mathrm{mg}$. In the USP (United States Pharmacopeia), in the General Tests and Assays for Nutritional Supplements section, the monograph for melatonin tablets includes the dissolution test [8], however no requirements were found for melatonin sublingual tablets, therefore the aim of the present study was to develop a discriminative dissolution method for melatonin sublingual products by using experimental design. 


\section{Materials and Methods}

\section{Reagents and equipment}

Melatonin certified reference material was purchased from Sigma-Aldrich Co. (St. Louis MO, USA). Methanol and acetonitrile HPLC-grade, sodium acetate, potassium dihydrogen phosphate and sodium hydroxide were obtained from J.T. Baker. Distilled or deionized water was obtained from the Elix 3 and Milli-Q water purification system (Millipore, Milford, MA, USA) respectively. $35 \mu \mathrm{m}$ full flow filters (Agilent Tech.), $0.45 \mu \mathrm{m}$ membrane (Durapore ${ }^{\circledR}$ ) were used.

The dissolution studies were performed using USP Apparatus 2 Vankel, VK 7000 (Varian Inc., USA). Melatonin quantification in the dissolution studies was performed using a dual beam UV-Visible spectrophotometer system (Shimadzu Corporation). The HPLC system, used for quality control tests of melatonin, consisted of a dual plunger pump (LC-10ATVP, Shimadzu, Kyoto, Japan), a UV-Vis detector (SPD10AVP, Shimadzu) equipped with system controller (CBM-20A, UFLC, Shimadzu), and an (SIL-10A) autosampler (Shimadzu).

\section{Samples}

For the experimental design, one commercial batch of the Mexican reference sublingual tablet $5 \mathrm{mg}$ product $\left(\right.$ Benedorm ${ }^{\circledR}$ ) was used. For the method evaluation, two commercial batches of the reference product and two commercial batches of two melatonin (5 mg) sublingual generic products were selected. All products were commercially available in Mexico and were randomly coded, such as: R1, R2 (reference product) and A1, A2, B1, B2 (generic products).

\section{Solubility assay}

The saturation solubility of melatonin was determined in four different media: $\mathrm{HCl}(\mathrm{pH} 1.2)$, acetate buffer ( $\mathrm{pH} 4.5$ ), phosphate buffer ( $\mathrm{pH}$ 6.8) and water. Briefly, an excess of the drug was added to each glass tube containing $5 \mathrm{~mL}$ of each of the media. Samples were shaken at $37 \pm 0.5^{\circ} \mathrm{C}$ for $72 \mathrm{~h}$. An aliquot was filtered through a $0.45 \mu \mathrm{m}$ membrane and diluted with the respective medium for its quantification. The concentration of melatonin was determined by measuring the absorbance at $220 \mathrm{~nm}$ and interpolated in its respective calibration curve. In each media the experiment was performed in triplicate.

\section{Quality control tests}

Considering that there is no monograph available for melatonin sublingual tablets, the products were evaluated for strength and weight variation, according to the procedures described in the USP for melatonin tablets [8]. Additionally, colour and shape description as well as uniformity of dosage units (content uniformity) were performed. This last test was carried out according to the general procedure for tablets described in the USP.

Stability assay

The stability of melatonin in the dissolution media, water and phosphate buffer pH 6.8, was assessed. Sample solutions of $1 \mu \mathrm{g} / \mathrm{mL}$ and $12 \mu \mathrm{g} / \mathrm{mL}$ were prepared and then analysed spectrophotometrically at $220 \mathrm{~nm}$. The analysis was performed at time zero, after $4 \mathrm{~h}$ at room temperature and up to $72 \mathrm{~h}$ under refrigeration. The absolute differences between the results at time zero and the time of analysis were used as stability indicator.

\section{Dissolution method development}

Design of experiments (DOE) type 2 was employed to assess the relationship between the Factors acting on the dissolutions test, using media, agitation rate and sampling time as critical test parameters. Table I shows the characteristics of the DOE. Each variable of the design had two different levels (- and +). Table II shows the conditions of each of 8 dissolution tests that were performed using six units of the reference product in each test. In all experiments, 5 $\mathrm{mL}$ samples were withdrawn at each sampling time without medium reposition. Samples were filtered through $35 \mu \mathrm{m}$ filters and assayed using a spectrophotometric method at $220 \mathrm{~nm}$, previously validated in both dissolution media. The method was linear between 1 and $12 \mu \mathrm{g} / \mathrm{mL}$. Intra-day and inter-day coefficients of variation were $<2 \%$.

\section{Statistical analysis}

All the data were analysed using DDsolver software. The level of significance was set at $p<0.05$ [9].

Table I

DOE Factors and levels studied

\begin{tabular}{|c|c|c|}
\hline Factor & Low level (-) & High level (+) \\
\hline $\begin{array}{c}\text { Sampling times (St) } \\
\text { A }\end{array}$ & St 1 & St 2 \\
B & $1,4,12,16$ and $20 \mathrm{~min}$ & $2,6,10,14,18$ and $20 \mathrm{~min}$ \\
\hline $\begin{array}{c}\text { Dissolution media } \\
\text { Agitation rate } \\
\text { C }\end{array}$ & Distilled water & Buffer $\mathrm{pH} 6.8$ \\
\hline
\end{tabular}


Conditions of the dissolution tests according to the experimental design

\begin{tabular}{|c|c|c|c|}
\hline Experiment/Variable & $\begin{array}{c}\text { A } \\
\text { Sampling time }(\mathrm{St})\end{array}$ & $\begin{array}{c}\text { B } \\
\text { Medium }\end{array}$ & $\begin{array}{c}\mathrm{C} \\
\text { Agitation rate }\end{array}$ \\
\hline 1 & St 1 & Distilled water & $50 \stackrel{-}{\mathrm{rpm}}$ \\
\hline 2 & $\begin{array}{c}+ \\
\text { St } 2\end{array}$ & $\begin{array}{c}- \\
\text { Distilled water }\end{array}$ & $50 \stackrel{-}{\mathrm{rpm}}$ \\
\hline 3 & St 1 & $\begin{array}{c}+ \\
\text { Phosphate Buffer pH } 6.8\end{array}$ & $50 \stackrel{-}{\mathrm{rpm}}$ \\
\hline 4 & $\begin{array}{c}+ \\
\text { St } 2 \\
\end{array}$ & $\begin{array}{c}+ \\
\text { Phosphate Buffer pH } 6.8\end{array}$ & 50 rpm \\
\hline 5 & St 1 & Distilled water & $\begin{array}{c}+ \\
75 \mathrm{rpm}\end{array}$ \\
\hline 6 & $\begin{array}{c}+ \\
\text { St } 2 \\
\end{array}$ & Distilled water & $\begin{array}{c}+ \\
75 \mathrm{rpm}\end{array}$ \\
\hline 7 & St 1 & $\begin{array}{c}+ \\
\text { Phosphate Buffer pH } 6.8\end{array}$ & $\begin{array}{c}+ \\
75 \mathrm{rpm}\end{array}$ \\
\hline 8 & $\begin{array}{c}+ \\
\text { St } 2\end{array}$ & $\begin{array}{c}+ \\
\text { Phosphate Buffer pH } 6.8\end{array}$ & $\begin{array}{c}+ \\
75 \mathrm{rpm}\end{array}$ \\
\hline
\end{tabular}

\section{Results and Discussion}

Quality control tests

Table III shows the quality tests performed for the different products under study. It can be seen that the products were similar in strength $(90.8-95.0 \%)$ as well as in content uniformity (95.0 - 100.9\%). Results showed that all the products evaluated met with the USP acceptance criteria of strength (90 $110 \%)$ and content uniformity $(\mathrm{L} 1<15)$. These results confirm the pharmaceutical equivalence among the marketed products studied. In a previous study, Eland and Saxena [10] evaluated 31 melatonin supplements and found that content was in the range from -83 to $+478 \%$ of the labelled claim. Additionally, batch to batch variability was as much as $465 \%$. The authors highlighted the need for comprehensive characterization and standardization of melatonin supplements. In the case of the Mexican products, we found a homogeneous quality, which could be related to the fact that they are registered as medicinal products.

Table III

Physicochemical characteristics of melatonin $(5 \mathrm{mg})$ sublingual products

\begin{tabular}{|c|c|c|c|c|c|c|}
\hline Product & Colour & Shape & $\begin{array}{c}\text { Average Weight } \\
(\mathrm{mg} \pm \mathrm{SD})\end{array}$ & $\begin{array}{c}\text { Weight Variation } \\
(\% \text { range variation }) \\
\mathrm{N}=20\end{array}$ & $\begin{array}{c}\text { Strength } \\
(\%) \pm \mathrm{SD}\end{array}$ & $\begin{array}{c}\text { Content } \\
\text { uniformity } \\
(\%) \pm \mathrm{SD}\end{array}$ \\
\hline R1 & White & flat-faced bevel-edged & $120.9 \pm 0.9$ & -1.56 to 1.66 & $93.5 \pm 1.5$ & $95.0 \pm 1.9$ \\
R2 & & and bisect line & $120.3 \pm 0.7$ & -1.08 to 1.33 & $94.9 \pm 0.2$ & $100.9 \pm 4.5$ \\
\hline A1 & White & flat-faced bevel-edged & $120.5 \pm 0.9$ & -1.16 to 1.90 & $91.1 \pm 1.2$ & $95.7 \pm 2.1$ \\
A2 & & and bisect line & $120.4 \pm 0.7$ & -1.44 to 1.29 & $90.8 \pm 0.5$ & $95.6 \pm 1.3$ \\
\hline B1 & White & standard convex & $101.9 \pm 0.9$ & -1.93 to 1.40 & $94.2 \pm 0.7$ & $98.4 \pm 4.3$ \\
B2 & & & $102.1 \pm 0.7$ & -1.46 to 1.48 & $95.0 \pm 1.9$ & $95.4 \pm 3.2$ \\
\hline
\end{tabular}

\section{Solubility assay}

Results showed that solubility of melatonin was $\mathrm{pH}$ independent with values of $2.2 \mathrm{mg} / \mathrm{mL}, 2.5 \mathrm{mg} / \mathrm{mL}$ and $2.7 \mathrm{mg} / \mathrm{mL}$ at $\mathrm{pH} 1.2, \mathrm{pH} 4.5$ and $\mathrm{pH} 6.8$ respectively, which can be associated to its neutral characteristics. The obtained value in water was $2.5 \mathrm{mg} / \mathrm{mL}$, which is in accordance with that previously reported [11]. These results confirm that the dissolution studies were performed under sink conditions.

According to the Biopharmaceutical Classification System, Do values were calculated, using the formula Do = Maximum Dose $/ 250 \mathrm{~mL} /$ Solubility. In the case of melatonin products, the maximum dose available in the market is $10 \mathrm{mg}$. Do values were: $0.018,0.016$, 0.015 and 0.016 at $\mathrm{pH} 1.2, \mathrm{pH} 4.5, \mathrm{pH} 6.8$ and water, respectively, therefore melatonin can be considered as a high solubility compound.

Stability assay

Results of the present study showed that melatonin was stable in water and in phosphate buffer $\mathrm{pH} 6.8$ during $72 \mathrm{~h}$ in refrigeration and at least until $4 \mathrm{~h}$ at room temperature $\left(20^{\circ} \mathrm{C}\right)$. The results are in agreement with those reported by Daya et al. [12] which found that melatonin was stable at room temperature and at $37^{\circ} \mathrm{C}$ over the $\mathrm{pH}$ range $1.2-12$ for at least 2 days. Dissolution Method Development

Figure 1 shows the dissolution profiles obtained from the experimental design using the dissolution conditions presented in Table II. As can be seen, the sampling times selected allowed to characterize properly all the phases of the dissolution process. 


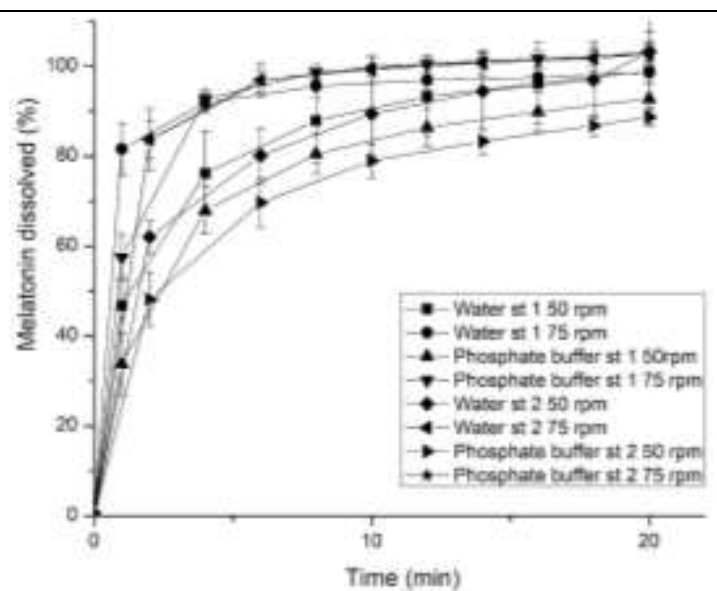

Figure 1.

Melatonin Dissolution Profiles using factorial experimental design $(\mathrm{st}=$ sampling time $)$

Experimental data were adjusted to a Weibull model and the $\%$ dissolved values were predicted at 2, 4, 6 , 8 and 12 min for each experimental condition. With this calculated data, $f_{2}$ tests were performed until 12 min. Table IV shows that only C Factor (agitation rate), gave $f_{2}$ values lesser than 50 ; similar results were obtained with Pareto test (Figure 2), indicating that the significant effect was related to $\mathrm{C}$ Factor. Data also showed that sampling times had not a considerable effect on the dissolution results.

Table IV

$f_{2}$ test comparing experiment 1 against all other experiments

\begin{tabular}{|l|c|c|c|c|c|c|c|}
\hline Comparison & A & B & AB & C & AC & BC & ABC \\
\hline$f_{2}$ at 12 min & 94.7 & 50.6 & 43.3 & 41.3 & 44.1 & 44.0 & 41.1 \\
\hline
\end{tabular}

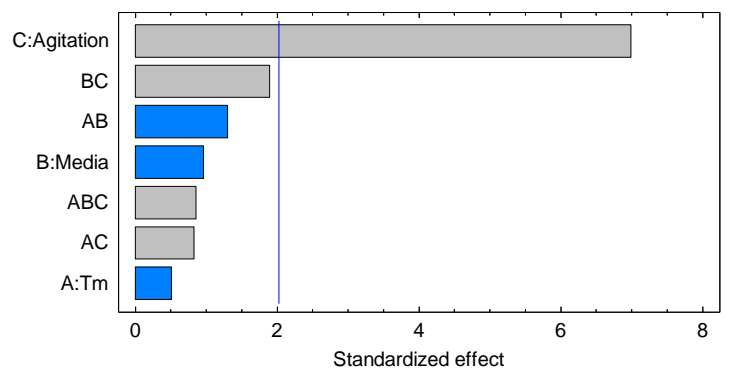

Figure 2.

Pareto test for melatonin using percent dissolved at $12 \mathrm{~min}$ as response variable

Based on this information and considering that there were no differences among dissolution media, water was chosen because it is the simplest medium. A 50 rpm agitation rate was chosen, considering that the ascending phase could be more adequately characterized than with $75 \mathrm{rpm}$. This result could be related to the hydrodynamic effect of the agitation rate, since an increase of the flow pattern has been observed between 25 and $150 \mathrm{rpm}$, mainly in the early sampling times [13]. Therefore, the conditions selected were: USP Apparatus 2, $50 \mathrm{rpm}, 500 \mathrm{~mL}$ of water and sampling times 2, 4, 6, 8, 12 and $20 \mathrm{~min}$.

With these conditions, two batches of the reference product and 2 batches of other two products marketed in Mexico were evaluated. Figure 3 shows the dissolution profiles obtained. It can be seen that at 2, 4 and 6 minutes, the reference products dissolved faster than the generic products, which indicate the discriminative capacity of the method developed.

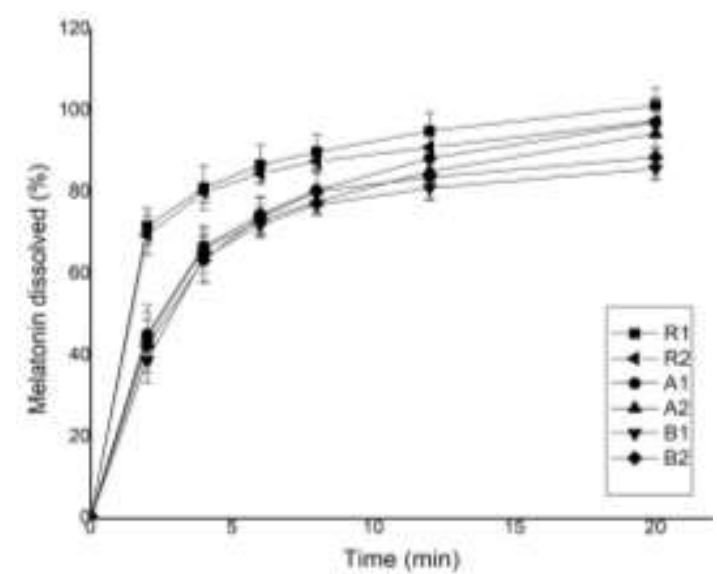

Figure 3.

Dissolution profiles of different sublingual products containing melatonin $5 \mathrm{mg}(\mathrm{n}=12)$

In order to determine the differences between products, $f_{2}$ test was calculated until $12 \mathrm{~min}$. Results are shown in Table V. Although differences were observed between the generic products and the reference product batches, no differences were found within and between generic drug products $\left(f_{2}>50\right)$. These results could be related to differences in formulations or manufacturing process among reference and generic products.

Table V

Dissolution profiles comparison of Mexican commercial products by using $f_{2}$ at 12 minutes

\begin{tabular}{|c|c|c|c|c|c|c|c|c|c|}
\hline Comparison & $\mathrm{R}_{1} v s . \mathrm{R}_{2}$ & $\mathrm{~B} v s . \mathrm{R}_{1}$ & $\mathrm{~B}_{2} v s . \mathrm{R}_{1}$ & $\mathrm{~A}_{1} v s . \mathrm{R}_{1}$ & $\mathrm{~A}_{2} v s . \mathrm{R}_{1}$ & $\mathrm{~B}_{1} v s . \mathrm{B}_{2}$ & $\mathrm{~A}_{1} v s . \mathrm{A}_{2}$ & $\mathrm{~A}_{1} v s . \mathrm{B}_{1}$ & $\mathrm{~A}_{2} v s . \mathrm{B}_{2}$ \\
\hline$f_{2}$ at $12 \mathrm{~min}$ & 778 & 35 & 38 & 40 & 39 & 78 & 82 & 65 & 82 \\
\hline
\end{tabular}

Sublingual drug delivery has been used for the formulation of many drugs with the viewpoint of rapid release and fast action. Sublingual products are also developed in order to overcome the difficulty in swallowing of tablets and capsules in geriatric patients with dysphagia. To date melatonin tablets and capsules are frequently used, however the number of sublingual products is growing. Few information is available about dissolution behaviour of melatonin products. Hahm $\mathrm{H}$ et al., evaluated the dissolution profiles of five immediate-release, two sublingual, and two controlled-release products using Apparatus 2 at $75 \mathrm{rpm}$ and $0.1 \mathrm{~N} \mathrm{HCl}$ at $37 \pm 0.5^{\circ} \mathrm{C}$. They found a broad difference in the in vitro results. Four immediate- 
FARMACIA, 2021, Vol. 69, 1

release products dissolved less than $75 \%$ in 1 hour. Also, one of the controlled-release drug products released the $90 \%$ of its content in 12 hours. In the case of sublingual products both dissolved more than $80 \%$ in 1 hour [14].

Actually, the dissolution test requirements for melatonin capsules of the British Pharmacopoeia [15] are Apparatus 2, at $50 \mathrm{rpm}, 900 \mathrm{~mL}$ of $0.1 \mathrm{M}$ hydrochloric acid and a sampling time of 45 minutes. The USPrecommended method for melatonin immediate-release tablets is $500 \mathrm{~mL}$ of water, Apparatus 2, at $50 \mathrm{rpm}$, and a sampling time of 30 minutes.

As of our knowledge, this is the first study that evaluates the dissolution characteristics of sublingual tablets with melatonin. Our results indicate that the USP conditions used for immediate-release tablets could also be adequate for the evaluation of the dissolution profile of sublingual tablets using 2, 4, 6, 8 and 12 minutes as sampling times.

\section{Conclusions}

A novel in vitro method is proposed for the assessment of dissolution for melatonin sublingual tablets. The method, developed by using experimental design, allowed to discriminate between products.

The experimental conditions USP Apparatus 2, $50 \mathrm{rpm}$ and $500 \mathrm{~mL}$ of water as dissolution medium, can be used for dissolution profiles comparison of products in this dosage form.

\section{Acknowledgement}

This work was financially supported by Project PAPIIT IN- 223019 DGAPA UNAM.

\section{Conflict of interest}

The authors declare no conflict of interest.

\section{References}

1. Reiter RJ, The melatonin rhythm: both a clock and a calendar. Experientia, 1993; 49: 654-664.

2. Acuña-Castroviejo D, Escames G, Venegas C, DíazCasado ME, Lima-Cabello E, Lopez L, Rosales-Corral S, Tan DX, Reiter RJ, Extrapineal melatonin: sources, regulation and potential functions. Cell Mol Life Sci., 2014; 71: 2997-3025.

3. Zisapel N, New perspectives on the role of melatonin in human sleep, circadian rhythms and their regulation. Br J Pharmacol., 2018; 175(16): 3190-3199.
4. Hardeland R, Cardinali DP, Srinivasan V, Spence DW, Brown GM, Pandi-Perumal SR, Melatonin - a pleiotropic, orchestrating regulator molecule. Prog Neurobiol., 2011; 93(3): 350-384.

5. Van den Berg MP, Merkus P, Romeijn SG, Verhoef JC, Merkus FW, Uptake of melatonin into the cerebrospinal fluid after nasal and intravenous delivery: studies in rats and comparison with a human study. Pharm Res., 2004; 21: 799-802.

6. Johns J, Estimation of melatonin blood brain barrier permeability. J Bioanal Biomed., 2011; 3(3): 66-69.

7. IOM, 2004. Institute of Medicine Committee on the Framework for Evaluating the Safety of Dietary Supplements. Prototype monograph on melatonin. Dietary Supplement Ingredient Prototype Monographs, Developed as Examples for the Report Dietary Supplements: A Framework for Evaluating Safety. Institute of Medicine and the National Research Council of the National Academies, Washington (DC): National Academies Press 2004: D1-D71.

8. USP 42/NF 37. United States Pharmacopeia. The National Formulary. U.S. Pharmacopeial Convention, Inc, Rockville, M.D. 2019; 5130-5131.

9. Zhang Y, Huo M, Zhou J, Zou A, Li W, Yao C, Xie S, DDsolver: An add-in program for modeling and comparison of drug dissolution profiles. The AAPS J., 2010; 12(3): 263-271.

10. Erland LA, Saxena PK, Melatonin Natural Health Products and Supplements: Presence of Serotonin and Significant Variability of Melatonin Content. $J$ Clin Sleep Med., 2017; 13(2): 275-281.

11. Scientific Committee on Consumer Safety SCCS. OPINION ON Melatonin. European Union, 2010. ISBN 978-92-79-12738-0. Meeting 23 March 2010 https://ec.europa.eu.

12. Daya S, Walker RB, Glass BD, Anoopkumar-Dukie $\mathrm{S}$, The effect of variations in $\mathrm{pH}$ and temperature on stability of melatonin in aqueous solution. $J$ Pineal Res., 2001; 31(2): 155-158.

13. Todaro V, Persoons T, Grove G, Healy AM, D'Arcy $\mathrm{D}$, Characterization and simulation of hydrodynamics in the paddle, basket and flow-through dissolution testing apparatuses. A review. Dissolution Technol., 2017; 24(3): 24-36.

14. Hahm H. Kujawa J. Augburger L, Comparison of melatonin products against USP Nutritional Supplements Standards and other criteria. J Am Pharm Assoc., 1999; 39(1): 27-31.

15. The British Pharmacopoeia British Pharmacopoeia; TSO: London, UK, 2020. 